\title{
HEPATITIS-C VIRUS INFECTION; SEROPREVALENCE AND RISK FACTORS IN STAFF NURSES OF LAHORE, PAKISTAN
}

1. Provincial TB Control Program Punjab,

Directorate of General health Services Punjab, Lahore

2. College of Home Economics, Gulberg, Lahore

3. Allama Iqbal Medical College, Lahore

4. Provincial TB Control Program Punjab,

Directorate of General Health Services Punjab, Lahore

5. Department of Microbiology and Molecular Genetics,

University of the Punjab, Lahore.

Correspondence Address:

Hasnain Javed

PhD Scholar,

Department of Microbiology and

Molecular Genetics,

University of the Punjab, Lahore

hasnain_javed@hotmail.com

Article received on:

09/06/2015

Accepted for publication:

00/00/2015

Received after proof reading:

$12 / 10 / 2015$

\section{Novelty Statement}

The study reveals a higher prevalence of $\mathrm{HCV}$ infection in Staff Nurses from various public and private sector hospitals of Lahore. It highlights that especially nurses of surgical wards are more infected with HCV than other wards.

\section{INTRODUCTION}

Hepatitis C is serious global public health problem with health care workers at more risk of getting infection especially in resource limited settings. Hepatitis is a disease characterized by inflammation of the liver, usually producing swelling and, in many cases, permanent damage to liver tissues. Globally Hepatitis C infects 3 to 4 million people per annum ${ }^{1}$ however and it is generally considered that its prevalence is expected to surpass all other blood borne infectious diseasesparticularly among certain risk groups. ${ }^{2}$ Pakistan has documented high prevalence of anti-HCV and active HCV infection from Lahore and other regions of Punjab. $3,4,5$ Determination of genotypes provides relevant clinical information and particularly response in interferon treatment. In published reports of distribution of different HCV genotypes within the Pakistani population, the most predominant HCV genotype is genotype $3 a$ i.e. 75 percent to 90 percent, followed by genotypes 1,2 , and $5.6,7$

Blood borne infections are usually considered occupational hazard for years and they also share common route of transmission. ${ }^{8}$ Nursing staff is at the forefront of exposure to HCV due to needle stick injuries and non precautionary measures in high burden resource limited countries. Accidental needle stick injuries are considered most associated risk factor for transmission of 
Hepatitis $\mathrm{B}$ and $\mathrm{C}$ among health care workers. ${ }^{9}$ The nurses constantly place themselves in potential danger, by attending to infected patients. ${ }^{10}$ While acquiring infection from an infected patient is common, transmitting infection from an infected HCW to a patient is also being documented in an increasing frequency. The present study aimed to investigate the seroprevalence of Hepatitis $\mathrm{C}$ among nurses in population of Lahore Metropolitan city and to evaluate the risk factors of hepatitis $\mathrm{C}$ infection in the nurses. It also aimed to find out any relationship between their working area and the incidence of HCV infection andto find the distribution of genotypes of HCV in AntiHCV positive nurses.

\section{METHODS}

Present study was carried out to observe the prevalence of laboratory based confirmed Hepatitis-C patients nurses among the population of Lahore metropolitan. For collection of data on a pretested questionnaire (to study the risk factors associated with HCV infection) and blood samples, a convenient sampling technique was used in nursesbelonging to different public sector and private hospitals of Lahore city. This study was approved by the ethical committee of the University of veterinary and Animal Sciences Lahore. After taking informed consent from enrolled nurses, the pre-tested questionnaire were got filled (to study the risk factors associated with $\mathrm{HCV}$ infection) during the period of one year (January 2013 to December 2013). All the samples were processed for Anti-HCV antibody detection through ELISA and third generation ELISA Kit (ETI-AB-HCVK-4, Diasorin S.P.A Italy) containing 96 wells was used for Enzyme Linked Immunosorbent Assay. ${ }^{11}$ To study the different genotypes of Hepatitis-C virus, the Anti-HCV positive serum samples were subjected to Real time PCR(RT-PCRCepheid smart cycler was applied by using QIAamp Mini column kit and Sacace HCV Genotyping kit). In this study the data so collected was analyzed statistically by using SPSS (version 16). ${ }^{12}$ All the quantitative data was presented in the form of frequency, percentage and mean \pm S.D. The qualitative data was presented in the form of proportion and percentage where appropriate. For quantitative data, t-test for independent sample was used for analytical statistics. Chi-square test was used to analyze the qualitative data. A P-value $<0.05$ was considered to be significant. Odds Ratio with 95\% Confidence interval was used to see the magnitude of dependency on various risk factors.

\section{RESULTS}

A total of 186 nurses were enrolled and screened for Anti HCV in the study. Out of these 9 (4.83\%) nurses were reactive for Anti-HCV. The mean age of reactive and non-reactive nurses was $22.33 \pm 1.15$ and $23.66 \pm 1.97$ years, respectively. The mean age was insignificantly associated ( $p$-value $>0.05$ ) with HCV infection in nurses as given in table-l.

\begin{tabular}{|c|c|c|c|}
\hline & \multicolumn{2}{|c|}{ Anti HCV Status } & \multirow{2}{*}{ Total } \\
\hline & Reactive & Non-Reactive & \\
\hline Number (\%) & $9(4.83 \%)$ & 177 (95.16\%) & 186 \\
\hline Mean(Age) & 22.33 & 23.66 & 23.60 \\
\hline Std. Deviation & 1.15 & 1.97 & 1.95 \\
\hline \multicolumn{4}{|c|}{$\begin{array}{l}\text { Table-I: Distribution of reactive (Positive) \& non- } \\
\text { reactive (Negative) Staff Nurses from healthy } \\
\text { population of Lahore Metropolitan } \\
P \text {-value }=0.525 \text { statistically insignificant at } 5 \% \alpha \text { level }\end{array}$} \\
\hline
\end{tabular}

As far as the marital status of these positive nurses is concerned, all were un-married. Marital status with respect to Anti-HCV status was not found to be statistically significant (P-value $>0.05$ ). The monthly income of all these nurses was $<$ Rs.20,000 PKR. Among these 9 nurses who were found reactive, 03 was student of B.Sc. nursing and the remaining 06 nurses had qualified B.Sc. nursing and were employed at rank of staff nurses $(P$-value $<0.05)$ as shown in table-II.

The data on working experience of nurses who were found reactive for anti-HCV was collected. All the reactive nurses revealed that they had experience of working in surgical wards. Working experience was significantly associated with AntiHCV status $(p<0.05)$. All these 9 HCV positive nurses had history of treating HCV patients. 03 nurses gave the past history of being pricked by sharp objects out of 09 reactive nurses. The association of being pricked by sharp objects 


\begin{tabular}{|c|c|c|c|c|c|c|c|}
\hline \multirow{2}{*}{\multicolumn{2}{|c|}{ Demographic Characteristics }} & \multicolumn{2}{|c|}{ Anti HCV Status } & \multirow{4}{*}{$\begin{array}{c}\text { P-value } \\
-\end{array}$} & \multirow{4}{*}{$\begin{array}{c}\text { Odds } \\
\text { Ratio } \\
-\end{array}$} & \multirow{2}{*}{\multicolumn{2}{|c|}{ Confidence Interval }} \\
\hline & & \multirow{3}{*}{$\begin{array}{c}\text { Reactive } \\
- \\
99\end{array}$} & \multirow{3}{*}{$\begin{array}{c}\text { Non-Reactive } \\
- \\
177\end{array}$} & & & & \\
\hline \multirow{2}{*}{ Gender } & Male & & & & & 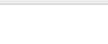 & 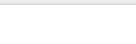 \\
\hline & Female & & & & & - & - \\
\hline Educational Status & B.Sc. Nursing & 9 & 177 & - & - & - & - \\
\hline \multirow{2}{*}{ Marital Status } & Married & 0 & 9 & \multirow{2}{*}{0.593} & \multirow{2}{*}{2.306} & \multirow{2}{*}{0.09} & \multirow{2}{*}{54.01} \\
\hline & Un-Married & 9 & 168 & & & & \\
\hline \multirow{2}{*}{ Rank } & Student & 3 & 3 & \multirow{2}{*}{0.002} & \multirow{2}{*}{0.034} & \multirow{2}{*}{0.002} & \multirow{2}{*}{0.773} \\
\hline & Staff Nurse & 6 & 174 & & & & \\
\hline
\end{tabular}

and anti-HCV status was found statistically insignificant i.e. $p$-value $>0.05$. Out of 09 reactive nurses for anti-HCV, none had a history of neither surgery nor history of blood transfusion or visiting any dentist ( $p$-value $>0.05$ ). Among 09 reactive nurses Only 06 had a habit of going to beauty salon. According to $p$-value significant association was present for visit to beauty salon with respect to Anti-HCV status. i.e. p-value $<0.05$, $\mathrm{OR}=0.622$ However, the purpose for which they visited beauty salon was significantly associated with Anti-HCV status. i.e. $p$-value $<0.05$ as shown in table-III.

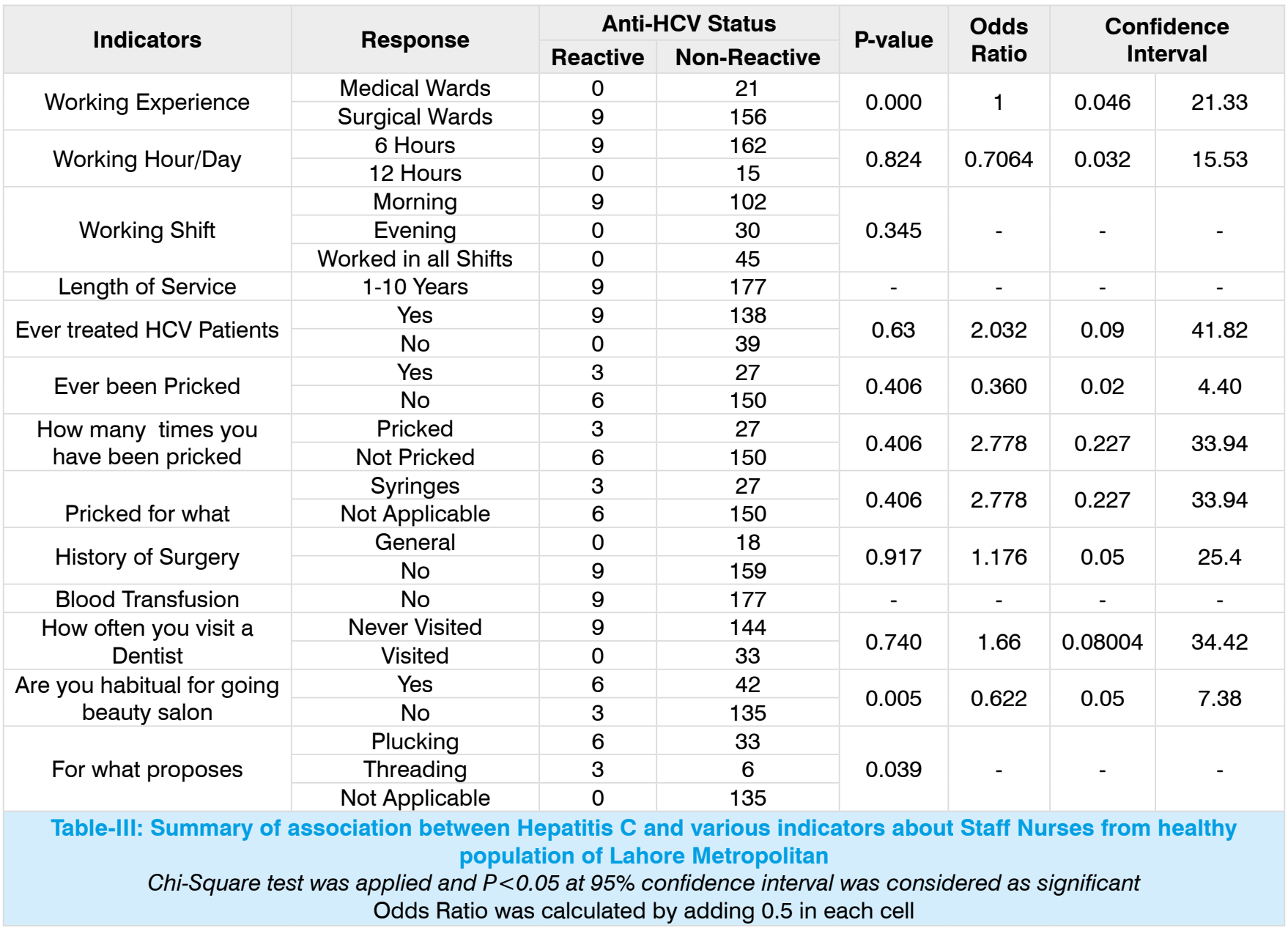


Table-IV summarizes the distribution of $\mathrm{HCV}$ genotypes in nurses. Among 186 respondents reactive for Anti-HCV, 08 patients' viral genotype was Type-3 and subtype detected was $3 a$, and 01 patients had un-typeable viral genotype.

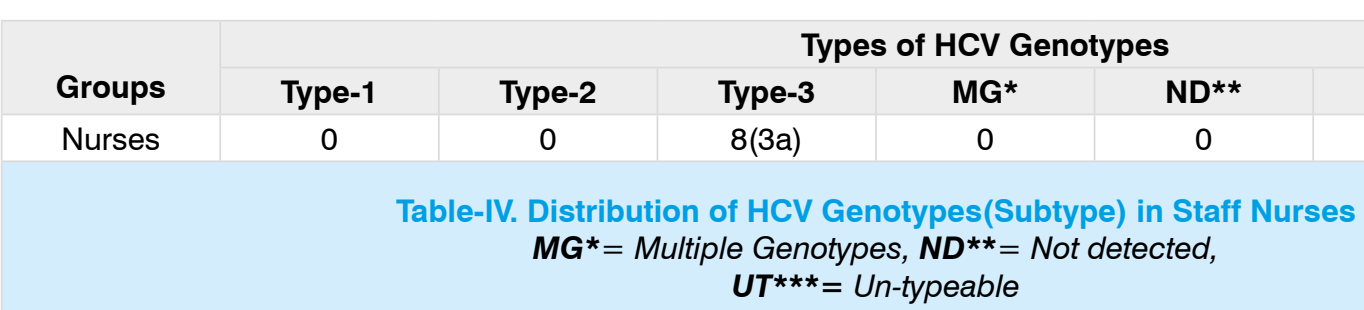

\begin{tabular}{|c|c|c|c|c|c|c|c|}
\hline Groups & Type-1 & Type-2 & Type-3 & MG* & ND** & UT*** & Total \\
\hline Nurses & 0 & 0 & $8(3 a)$ & 0 & 0 & 1 \\
\hline
\end{tabular}

\section{DISCUSSION}

Staff nurses are at forefront of the battle against blood borne viral and bacterial infections as they place themselves constantly in potential danger of acquiring infections as shown in our study that HCV prevalence was 4.83 percent which is alarmingly high in comparison with other studies (1.8 percent). ${ }^{13}$ Our study is in accordance with and Jindal et al. ${ }^{14} \mathrm{~A}$ study conducted in Pakistan reported very interesting facts about $\mathrm{HCV}$ prevalence of nursing staff i.e. $6 \%$ had HCV infection and $18 \%$ nurses had HBV infection. Moreover they also reported that $\mathrm{HCV}$ alone were seen in $5.6 \%$ of participants. HBV and HCV together were seen in $3.2 \%$ of positive cases..$^{15}$ Their findings are almost similar to the findings of the present study and some other reports in literature. ${ }^{16,17}$ Discussed in their study about the prevalence of $\mathrm{HCV}$, while they found it was most frequent and common in nurses. However prevalence of HCV can be found by screening total nursing staff of hospitals of Pakistan.

Results from the study of (Akhtar et al 2014) ${ }^{18}$ showed that a higher risk of HCV infection in pregnant women who had undergone any kind of surgical treatment. The present study recorded that all the reactive nurses were those who had experience of working in surgical wards. Working experience was significantly associated with AntiHCV status. All these 9 nurses who were reactive for anti-HCV have had history of treating HCV patients. According to the results of another study conducted in Lahore history of surgery and blood transfusion were significantly associated with anti-HCV status among blood donors whereas tattooing on the body was found to be the risk factor as the odds ratio was $3.0 .^{3}$

Copyright(@) 22 Aug, 2015.

\section{REFERENCES}

1. Fox JM, Newton R, Bedaj M, Keding A, Molyneux E, Carpenter LM, et al. Prevalence of Hepatitis $C$ virus in mothers and their children in Malawi. Tropical Medicine \& International Health. 2015.

2. Alqahtani JM, Abu-Eshy SA, Mahfouz AA, El-Mekki AA, Asaad AM. Seroprevalence of hepatitis $B$ and $C$ virus infections among health students and health care workers in the Najran region, southwestern Saudi Arabia: The need for national guidelines for health students. BMC public health. 2014;14(1):577.

3. Akhtar AM, Khan MA, ljaz T, Iqbal Z, Rana MY, Maqbool A, et al. Seroprevalence and determinants of hepatitis-C Virus infection in blood donors of Lahore, Pakistan. Pak J Zool. 2013;45:1-7.

4. Arshad A, Khan HU, Aslam MS, Rehman T, Arshad M, Ahmed MS, et al. Seropositivity and Active HCV Infection in Patients from Peshawar Division of Khyber Pakhtunkhwa Province, Pakistan. Pakistan Journal of Zoology. 2013;45(6):1579-84.

5. Salam A, Baloch BA, Khan N, Sarwar G. seroprevalence of hbsag (hbs) and anti-hcv; in general population of baluchistan. During 2012 and 2013. An awareness study.Professional Medical Journal. 2014;21(4).

6. Zaheer H, Saeed U, Waheed Y, Karimi S, Waheed U. Prevalence and Trends of Hepatitis B, Hepatitis C and Human Immunodeficiency Viruses among Blood Donors in Islamabad, Pakistan 2005-2013. J Blood Disorders Transf. 2014;5(217):2.

7. Nasim Z, Munir I, lqbal A, Ahmad M. Negligence of Hepatitis C Virus Genotyping in Pakistan: Reason for the Increasing Non-Responsiveness to Interferon Therapies. J AntivirAntiretrovir. 2015;6:153-.

8. Shah AA, Abidi SH, Kalish ML, Vermund SH, Ali S. Viral co-infections in high-risk communities of Pakistan. 
The Lancet HIV. 2015;2(4):e124-e5.

9. Bhardwaj A, Sivapathasundaram $N$, Yusof $M$, Minghat A, Swe K, Sinha N. The Prevalence of Accidental needle Stick Injury and their reporting among healthcare Workers in orthopedic Wards in General hospital Melaka, Malaysia. Malaysian orthopedic journal. 2014;8(2):6.

10. Mousley $\mathrm{N}$. Preventing infection in rehabilitation centres. Nursing Standard. 2015;29(38):43-7.

11. REBUZZINI G. Study of the hepatitis $\mathbf{C}$ virus NS3 helicase domain for application in a chemiluminescent immunoassay:UniversitàdegliStudi di Milano-Bicocca; 2009.

12. Kermani FR, Sharifi Z, Ferdowsian F, Paz Z, Tavassoli F. The Usefulness of Anti-HCV Signal to Cut-off Ratio in Predicting Viremia in Anti-HCV in Patients with Hepatitis C Virus Infection. JundishapurJournal of Microbiology. 2015;8(4).

13. Stevens A, Coyle P. Hepatitis $\mathbf{C}$ virus: an important occupational hazard? Occupational medicine. 2000;50(6):377-82.
14. Jindal N, Jindal M, Jilani N, Kar P. Seroprevalence of hepatitis $\mathrm{C}$ virus (HCV) in health care workers of a tertiary care centre in New Delhi. The Indian journal of medical research. 2006;123(2):179-80.

15. Adeel MY. Seroprevalence of hepatitis B and Hepatitis C in health care workers in Abbottabad. J Ayub Med Coll Abbottabad. 2008;20(3).

16. Zubair A, Jamal S, Mubarik A. Morphometric analysis of hepatic steatosis in chronic hepatitis $\mathbf{C}$ infection. Saudi journal of gastroenterology: official journal of the Saudi Gastroenterology Association.

2009;15(1):11.

17. Othman BM, Monem FS. Prevalence of hepatitis C virus antibodies among health care workers in Damascus, Syria. Saudi medical journal. $2001 ; 22(7): 603-5$.

18. Akhtar AM, Khan MA, ljaz T, Maqbool A, lqbal Z, Rehman $A$, et al. Hepatitis C Virus Infection in Pregnant Women in Lahore, Pakistan: An Analytical Cross Sectional Study. International Journal of Agriculture and Biology. 2014;16(1):160-4.

\section{PREVIOUS RELATED STUDY}

Dilshad Muhammad, Khalid Amin, Amin Anjum, Masood Javed. CHRONIC HEPATITIS C VIRUS INFECTION; ASSOCIATION WITH TYPE 2 DIABETES MELLITUS (Original) Prof Med Jour 17(4) 557-562 Oct, Nov, Dec 2010.

Muhammad Naeem, Ameer Ahmad, Imran Qaisar, Fiaz Ahmad. STATUS OF HEPATITIS C VIRUS (HCV) INFECTIONS; CHILDREN ADMITTED IN PEDIATRIC WARD OF BAHAWAL VICTORIA HOSPITAL BAHAWALPUR (Original) Prof Med Jour 18(3) 445-449 Jul, Aug, Sep 2011.

Sajjad Iqbal, Rashid Ahmed, Muhammad haroon Yousaf, Asim Mumtaz, Dawood Amin, Ghulam Rasool, Azmat Manzoor. HCV INFECTED PATIENTS; ASSESMENT OF MAJOR GENOTYPES AND SUBTYPES OF HEPATITIS C VIRUS (Original) Prof Med Jour 14(2) 266-271 Apr, May, Jun, 2007.

Muzaffar Mehmood Khan, Muhammad Tahir, Mohsin Raza, Muhammad Ali Bhatti, Muhammad Riaz Khokhar. Hepatitis C; association of interferon-ribavirin therapy with hearing loss (Original) Professional Med J Mar-Apr 2012;19(2): 193-196.

\section{AUTHORSHIP AND CONTRIBUTION DECLARATION}

\begin{tabular}{|c|l|l|}
\hline Sr. \# & \multicolumn{1}{|c|}{ Author-s Full Name } & \multicolumn{1}{|c|}{ Contribution to the paper } \\
\hline 1 & Dr. Abdul Majeed Akhtar & Pricinple Investigator \\
2 & Sadia Majeed & Co-Author (Data Analysis) \\
3 & Sufia Majeed & Co-Author (Data Collection) \\
4 & Shamsa Kanwal & $\begin{array}{l}\text { Co-Author (Data Analysis } \\
\text { Proof reading) } \\
\text { Proof Reading }\end{array}$ \\
5 & Hasnain Javed &
\end{tabular}

